\title{
EFFECT OF CURRENT, TIME, FEED AND CATHODE TYPE ON ELECTROPLATING PROCESS OF URANIUM SOLUTION
}

\author{
Sigit(1), Ghaib Widodo'), Bangun Wasito' ${ }^{2)}$, KrisTri Basuki'2), Fahrunissa ${ }^{2)}$ \\ ${ }^{1}$ Center for Nuclear Fuel Technology - BATAN \\ Kawasan Puspiptek, Serpong, Tangerang Selatan, 15314 \\ ${ }^{2}$ Polytechnic Institute of Nuclear Technology - BATAN \\ Jalan Babarsari Kotak Pos 6101 YKBB Yogyakarta 55281 \\ e-mail : sigit@batan.go.id
}

(Naskah diterima: 16-12-2016, Naskah direvisi: 20-01-2017, Naskah disetujui: 26-01-2017)

\begin{abstract}
EFFECT OF CURRENT, TIME, TYPE OF FEED AND CATHODE ON ELECTROPLATING PROCESS OF URANIUM SOLUTION. Electroplating of uranyl nitrate and process effluent has been carried out in order to collect uranium contained therein using $\mathrm{Pt} / \mathrm{Pt}$ and $\mathrm{Pt} / \mathrm{SS}$ electrodes at various current and time values. The materials used as electrode were Pt (platinum) and SS (Stainless Steel). Feed solution of $250 \mathrm{~mL}$ was entered into a beaker glass equipped with $\mathrm{Pt}$ anode - Pt cathode or Pt anode - SS cathode and connected to direct current source from DC power supply at various current values and for various time periods so that uranium precipitated and deposited onto the cathode. Upon deposition completion, the cathode was removed and weighed to determine weight of precipitates, while the solution was analyzed to determine uranium concentration decrease after electroplating process. The experiment shows that a relatively good time to acquire uranium deposit at the cathode was 1 hour at 7 ampere, with uranyl nitrate as feed and $\mathrm{Pt}$ (platinum) as cathode. In these conditions, uranium deposit attached to the cathode amounted to $74.96 \%$ of the original weight of uranium oxide in the feed or $206.5 \mathrm{mg}$ by weight. The use of Pt cathode for uranyl nitrate feed, and SS and Pt cathodes for effluent feed resulted in uranium specific weight at the cathode of $12.99 \mathrm{mg} / \mathrm{cm} 2,2.4 \mathrm{mg} / \mathrm{cm}^{2}$ and $5.37 \mathrm{mg} / \mathrm{cm}^{2}$ respectively for 7 Ampere current for 1 hour electroplating time.
\end{abstract}

Keywords: electroplating, uranyl nitrate, effluent process, $\mathrm{Pt} / \mathrm{Pt}$ electrode, $\mathrm{Pt} / \mathrm{SS}$ electrode. 


\section{ABSTRAK}

\section{PENGARUH ARUS, WAKTU, JENIS UMPAN DAN KATODA PADA PROSES} ELEKTROPLATING LARUTAN URANIUM. Telah dilakukan proses elektroplating dari larutan umpan uranil nitrat dan efluen proses dengan tujuan untuk memungut uranium yang terkandung di dalamnya menggunakan elektroda Pt/Pt dan Pt/SS pada berbagai arus dan waktu yang bervariasi. Bahan untuk elektroda adalah Pt (platinum) dan SS (Stainless Steel). Elektroplating dilaksanakan dengan memasukkan larutan umpan sebanyak $250 \mathrm{~mL}$ ke dalam gelas beaker yang dilengkapi dengan anoda Pt - katoda Pt atau anoda Pt - katoda SS, kemudian dialiri arus searah dari DC power supply dengan arus dan waktu tertentu sehingga terbentuk endapan uranium menempel di katoda. Setelah selesai, katoda dilepas dan ditimbang guna mengetahui berat endapan, sedangkan larutan dianalisis kandungan uraniumnya guna menentukan penurunan konsentrasi setelah dan sebelum proses elektroplating. Dari percobaan yang dilakukan diperoleh hasil bahwa waktu yang relatif baik untuk memperoleh endapan uranium di katoda adalah 1 jam dengan kuat arus 7 Ampere, umpan yang digunakan adalah larutan uranil nitrat dengan katoda Pt. Pada kondisi tersebut diperoleh endapan uranium yang menempel di katoda sebesar 74,96\% dari berat uranium oksida semula dalam umpan atau seberat 206,5 mg. Penggunaan katoda Pt untuk umpan uranil nitrat, katoda SS dan katoda Pt untuk umpan efluen proses diperoleh berat spesifik uranium di katoda masing-masing sebesar $12,99 \mathrm{mg} / \mathrm{cm}^{2}, 2,4 \mathrm{mg} / \mathrm{cm}^{2}$ dan $5,37 \mathrm{mg} / \mathrm{cm}^{2}$ untuk arus 7 amper dan waktu 1 jam.

Kata Kunci: elektroplating, uranil nitrat, efluen proses, elektroda Pt/Pt, elektroda Pt/SS. 


\section{INTRODUCTION}

Various activities carried out in chemical and nuclear industries always produce process residues either as solid or liquid waste, which can be dumped directly into the environment or recovered when the wastes contain ingredients that have economic value. The liquid process residues, also called process effluent, may still contain valuable materials. The residues can still be reprocessed to collect elements of high value. The process effluent resulted from the activities in nuclear industries may originated from such processes of dissolution of yellow cake, purification, extractionstripping and precipitation, which may still contain uranium. In those processes, yellow cake is dissolved in concentrated nitric acid to obtain solution of uranyl nitrate, which may still contains a lot of impurities, and subsequently purified by extraction-striping. Uranium is precipitated from uranyl nitrate solution with ammonium hydroxide to obtain ammonium diuranat (ADU). Yellow cake is obtained from uranium ore. The ores are processed through several stages of process such as breaking, dissolution, alkaline or acid leaching, extraction or ion exchange resin and precipitation ${ }^{[1,2]}$.

Uranium is a heavy element, which is toxic and radioactive with high mobility, and plays an important role in the nuclear industry, but must be handled properly so as not to pollute the environment ${ }^{[3]}$. The collection of uranium from process effluent, waste water, environmental water is therefore necessary ${ }^{[4]}$. Several methods of collecting uranium are evaporation, ion exchange, solvent extraction, transfer through a membrane and deposition ${ }^{[5,6]}$. These methods, however, are generally less effective for the discharge of pollutants in very small quantities and require substantial capital[7]. Development of methods were directed to solid phase extraction since it has advantages of simple, reliable, capable of obtain high enrichment factor and slight use of organic solvents. This method has been used for solid phase extraction of hexavalent uranium from solution[8].

Process effluent with high uranium concentration from a nuclear industry can be recovered by precipitation through AUC (ammonium uranyl carbonate) and ADU (ammonium diuranate) routes or the use of peroxide. Efficiency of deposition method can achieve up to $85 \%$, while the extraction process $80 \%$ [ ${ }^{[9]}$. Another method is a twochambered electrodialysis using cation exchange membrane and anion exchange membrane which can recover uranium from uranyl nitrate solution, where in that process the uranium in the feed decreases to $38.09 \%{ }^{[10]}$. Meanwhile, in a semi-continuous electroplating process of uranyl nitrate hexa hydrate with stainless steel (SS) electrodes for 1 hour process, uranium deposit collected were $21 \%$ and for liquid uranium waste the uranium obtained were $0.34 \%\left[{ }^{[11]}\right.$. These studies, however, did not yet determine the optimum conditions as a prolonged time may result in greater outcomes. Process is easier if the solution used without impurities compared to uranium waste solution containing uranium ${ }^{[11]}$. The process effluent from nuclear industry still contains various residual acids such as chloride, sulfate, nitrate ions and others with sufficiciently high acidity that need to be reduced by precipitation using $\mathrm{AgNO}_{3}, \mathrm{~Pb}\left(\mathrm{NO}_{3}\right)_{2}, \mathrm{Ba}\left(\mathrm{NO}_{3}\right)_{2}$, or formaldehyde. The filtrate obtained from the process can be used as feed in the electroplating process ${ }^{[12]}$.

Electroplating method has the advantage of process shortening compared to precipitation or extraction process. Therefore, in this research, the process of collecting uranium from uranyl nitrate and process effluent by electroplating method using platinum-platinum (Pt/Pt) and platinum-SS (stainless steel) (Pt/SS) electrodes is carried out to study the effect of time and electric current in the effort to obtain relatively pure 
uranium deposit and shortened process time compared to other methods.

Electroplating method is a metal and non-metal coating process using direct current (DC) of electrolysis principle ${ }^{[13]}$. The collection of uranium from a solution containing uranium can be done by electroplating method. The basis of electroplating method is electrolysis using two electrodes of an anode and a cathode like Pt/Pt and $\mathrm{Pt} / \mathrm{SS}$ electrodes. When electroplating process takes place, uranium ion and other positive ions will be attracted to and deposited as a precipitate at the cathode, and chemical reactions occur at the electrode and electrolyte, both reduction and oxidation reactions. Chemical reactions occur continuously and steadily towards a certain direction, so that the reactions require direct and constant current.

Electroplating principle is based on Faraday's law, which states that the number of substances formed due to an electrical current pasing through an electrolyte solution is directly proportional to the amount of electricity (coulomb) passing through, and the number of substances produced during the same electric current proportional to the electrolysis process equivalent weight. Statement of Faraday's law can be written in a formula ${ }^{[14]}$ :

$$
W=\frac{\text { I.t.Mw }}{\mathrm{nF}}
$$

where:

$$
\begin{aligned}
\mathrm{W} & =\text { weight of substances formed, } \mathrm{g} \\
\mathrm{I} & =\text { current strength used, } \mathrm{A} \\
\mathrm{t} & =\text { time }, \mathrm{S} \\
\mathrm{Mw} & =\text { molecular weight substances, } \\
& \mathrm{g} / \mathrm{mol} . \\
\mathrm{n} & =\text { number of electrons involved } \\
\mathrm{F} & =\text { Faraday number, } 96500 \mathrm{C} / \mathrm{mol}
\end{aligned}
$$

In this paper, electroplating method is used to collect uranium from uranium nitrate solution and process effluent as feed.
The recovered uranium may be converted to the form of $\mathrm{UO}_{2}, \mathrm{U}_{3} \mathrm{O}_{8}$ or others in the hope of it is reusable as nuclear fuel. Electroplating method can be used to collect uranium from solution due to the positive ions of uranium from uranyl nitrate solution that will be withdrawn and attached to the negatively charged cathode. The parameters studied include current strength, time, type of feed and cathode (platinum/Pt and stainless steel/SS). By varying the parameters, uranium deposit will be obtained at the cathode and a decline in the concentration of uranium in feed solution occurs after the electroplating process is completed. The amount of uranium deposit is determined by weighing the cathode plus deposit attached after electroplating process minus weight of the original cathode. The decrease in the concentration of uranium after electroplating process is the initial uranium concentration in the feed minus concentration of uranium after the electroplating process divided by initial uranium concentration in the feed. From the experiment, it is expected to obtain uranium attached at the cathode by means of electroplating.

\section{EXPERIMENTS}

Two types of materials used for feed are uranium oxide powder and process effluent solution from Experimental Fuel Element Installation with other process materials such as nitric acid, sodium hydroxide, phosphoric acid, sulfuric acid and some reagents for the analysis of uranium such as potassium di-chromate, acid sulfamic, ferrous sulfate, demineralized water.

The equipments used are an electroplating cell unit of glass beaker equipped with DC Power Supply as a current source and electrode $\mathrm{Pt} / \mathrm{Pt}$ or $\mathrm{Pt} / \mathrm{SS}$ (see Figure 1). Another tools used are $\mathrm{pH}$ meter, magnetic stirrer, heating furnaces, titroprosesor, and XRD. 
The initial stage of the experiment is the preparation of feed. The feed was prepared by dissolving uranium oxide powder with nitric acid to obtain a solution of uranyl nitrate. The other feed was process effluent solution which was filtered to remove impurities. The two materials were analyzed for uranium concentration and weight for use as feed solutions.

A total of $250 \mathrm{~mL}$ of uranyl nitrate feed solution or process effluent were put into a glass beaker and stirred. The anode and cathode electrodes were partially immersed into the solution which is connected to a DC power supply. The electrodes were worn washed and soaked first with nitric acid to remove impurities on the electrodes. The distance between the anode and the cathode was $2.5 \mathrm{~cm}$. The equipment was turned and the current flow started to occur in the solution with a setting of time, and it was turned off after the set time completed. The variables studied were the effect of the current strength, time, feed and cathode type used on the amount of uranium deposit at the cathode.

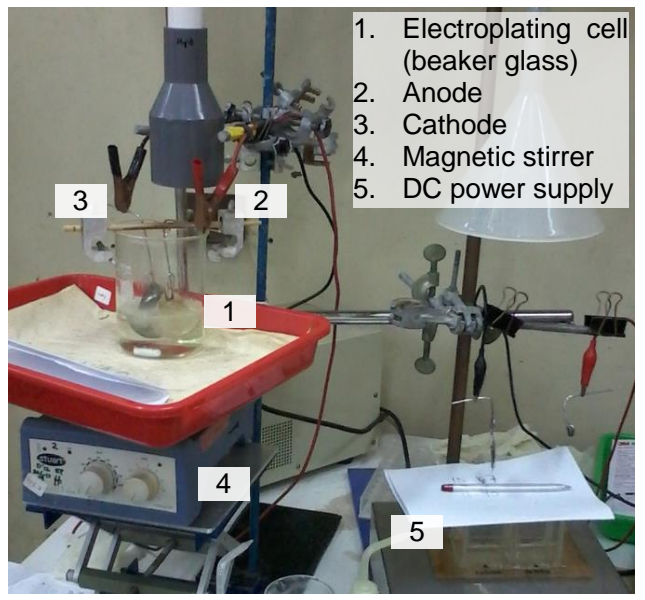

Figure 1. Electroplating cell unit

In this process electroplating, uranium ions will be attracted by the cathode and attached as precipitate. The precipitate and the cathode were dried and weighed to determine the weight of the precipitate obtained, while uranium concentration in the feed after process was also detemined.
Specific weight of the precipitate obtained was calculated by the weight of uranium deposit obtained divided by the effective cathode area immersed in the feed solution. The the effective cathode area was $15.9 \mathrm{~cm}^{2}$ for Pt cathode and $22.5 \mathrm{~cm}^{2}$ for SS cathode.

\section{RESULTS AND DISCUSSION}

Table 1 shows the result of analysis of uranyl nitrate concentration obtained from dissolving uranium oxide powder and analysis of process effluent that has been cleaned from impurities as well as weight of uranium in the two starting materials to determine the starting conditions. Uranyl nitrate and process effluent are used as feed in this study. The electrodes used were $\mathrm{Pt}$ anode and $\mathrm{Pt}$ cathode $(\mathrm{Pt} / \mathrm{Pt})$ pair for the uranyl nitrate feed and $\mathrm{Pt}$ anode and $\mathrm{SS}$ cathode (Pt/SS) pair for process effluent feed.

Table 1. Concentration and initial weight of uranium in uranyl nitrate and effluent process

\begin{tabular}{|l|c|c|}
\hline \multicolumn{1}{|c|}{ Feed } & $\begin{array}{c}\text { Conc. U, } \\
\text { ppm }\end{array}$ & $\begin{array}{c}\text { Uranium } \\
\text { oxide, } \mathrm{mg}\end{array}$ \\
\hline Uranyl nitrate & 971.28 & 275.49 \\
\hline Effluent process & 1008.12 & 282.66 \\
\hline
\end{tabular}

The uranyl nitrate feed is used in studying the effects of current strength and time toward number of uranium deposits attached to the cathode $\mathrm{Pt}$, while the effluent process feed for the uranium in the SS cathode.

\section{Effect of current and time using uranyl nitrate feed}

The influence of current to the amount of uranium deposit attached to the cathode was studied for various working current of $4 ; 5 ; 6$ and 7 ampers with electroplating process time for 1 hour. Electric current that flows between two electrodes in uranyl nitrate $\left(\mathrm{UO}_{2}\left(\mathrm{NO}_{3}\right)_{2}\right)$ solution feed causes the positive ionic charge $\left(\mathrm{UO}_{2}^{++}\right)$to be drawn by the cathode, 
while the negative ions $\left(\mathrm{NO}_{3}^{-}\right)$is attracted to the anode. When the direct current becomes stronger, displacement of charged ions towards the electrodes will occur, and more deposition of uranium will be attached to the cathode.

Chemical reactions occur at the cathode. The reactions involve the positively charged uranium ions, which eventually result in the attachment of uranium at the cathode ${ }^{\{15] .}$

$2 \mathrm{H}_{2} \mathrm{O}+2 \mathrm{e}^{-} \rightarrow \mathrm{H}_{2}+2 \mathrm{OH}^{-}$

$2 \mathrm{H}^{+}+2 \mathrm{e}^{-} \rightarrow \mathrm{H}_{2}$

$\mathrm{UO}_{2}{ }^{2+}+\mathrm{e}^{-} \rightarrow \mathrm{UO}_{2}+$

$\mathrm{UO}_{2}+4 \mathrm{H}^{+}+\mathrm{e}^{-} \rightarrow \mathrm{U}^{4+}+2 \mathrm{H}_{2} \mathrm{O}$

$\mathrm{U}^{4+}+\mathrm{e}^{-} \rightarrow \mathrm{U}^{3+}$

$\mathrm{U}^{3+}+3 \mathrm{e}^{-} \rightarrow \mathrm{U}_{(\mathrm{s})}$

The influence of current strength is indicated by a decrease of uranium concentration in the feed after the electroplating process is completed as shown in Figure 2. At lower current consumption, only small amount of precipitated uranium oxide is attached to the cathode and this amount multiplies when the current is set to higher strength. Higher current strength will increase the amount of deposit in the cathode according to the Faraday's law. With the increasing amount of uranium oxide attached at the cathode, the uranium content in the feed solution decreases. This can be seen in decreasing of the concentration as more deposit stuck to the cathode. The greatest amount of deposit attached to the cathode was formed for the working current of 7 amperes for time 1 hour electroplating process, which is equal to $74.96 \%$ of the initial uranium weight in the feed or as much as $206.5 \mathrm{mg}$. The electro-plating process that produces uranium deposit also affected in a way that the uranium concentration decreased in the feed after the process had ended. It was found that the concentration decreases from $8.49 \%$ to $91.19 \%$. Raising the ampere of current to above 7 could not be done due to tool's limitation, which caused a high temperature rise.

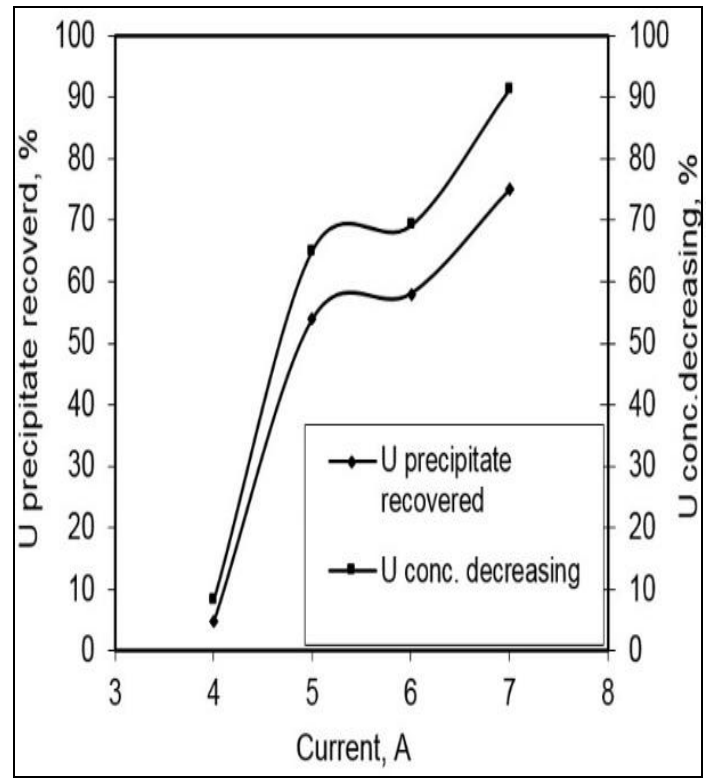

Figure 2. Effect of current on $\mathrm{UO}_{2}$ recovered weight and acidity decreasing of feed.

Variation in current strength above indicates a difference in function when the $\mathrm{UO}_{2}{ }^{++}$cations were drawn by the cathode. Time period used in electroplating process also has a role in determining the amount of uranium deposit attached to the Pt cathode. Time or duration of the electroplating process affects the amount of uranium that is attached to the Pt cathode. The influence of time on uranium attached to the cathode with constant current strength of 7 amperes can be seen in Figure 3. The longer time applied to the electroplating process results in more uranium deposit attached to the $\mathrm{Pt}$ cathode. Electroplating time of 1 hour gives the amount of uranium deposit at the greatest, which amounts to $74.96 \%$ of the original uranium in the feed or as much as $206.5 \mathrm{mg}$. 


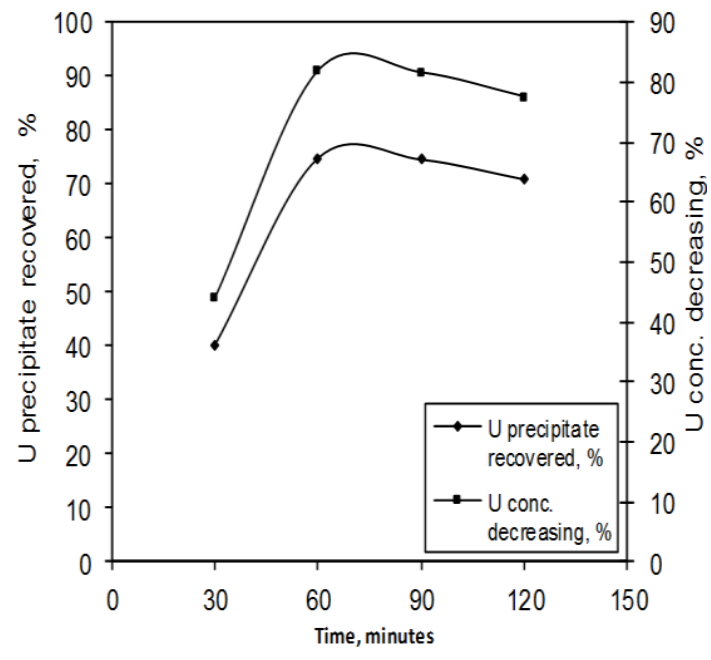

Figure 3. Effect of time on $\mathrm{UO}_{2}$ weight recovered and acidity decreasing of feed.

After 1 hour, however, the amount of deposit in the Pt cathode decreases, which is caused by the fact that the cathode surface is becoming saturated by uranium deposit or the previously attached uranium dissolves back into $\mathrm{UO}_{2}{ }^{++}$ion solution, or the weakly attached uranium releases from the Pt cathode. This occurance is caused by the reduced attracting power of the positive ions when the cathode surface is already covered by a layer of uranium deposit. Similar trend also occurs for the the uranyl nitrate feed solution. After the electroplating process has completed, a large amount of uranium concentration decreases in the solution. The initial uranium concentration in the feed solution is high and decreases as the electroplating process is progressing because the uranium is attracted by the cathode. Similarly, the highest uranium concentration reduction also occurs when the electroplating lasts for 1 hour, which is equal to $81.93 \%$.

From the experiment, the results obtained shows that a relatively good period of time to obtained the highest deposit produced at the cathode is 1 hour at a current strength of 7 amperes.

\section{Effect of current using effluent process feed}

By using the experimental results of uranyl nitrate as a feed, where the relatively good time is 1 hour, the electroplating process is continued by using a process effluent feed with current strength variation and the use of different cathode of SS $316 \mathrm{~L}$ and $\mathrm{Pt}$ as anode (Pt electrode/SS). The process effluent is a solution of a mixture of various waste products of process, such as waste products of laboratory analysis, purification and precipitation of uranium. The process effluent is different from the uranyl nitrate feed because it contains more impurities both metal and ions such as $\mathrm{NO}_{3}{ }^{-}, \mathrm{SO}_{4}{ }^{2-}$, $\mathrm{PO}_{4}{ }^{3-}, \mathrm{ClO}_{4}{ }^{-}$. The working current strength is varied from 5 to 8 amperes. Larger electric current causes displacement of ions in solution to increase. The negative ions move toward the Pt anode, while the positive ions to the SS cathode. Thus more amount of uranium deposit on the SS cathode will occur as the deposition process is progressing. The influence of current on the amount of deposit attached to the cathode indicates a decrease in the concentration of uranium in the process effluent solution, where the initial concentration was 1008.1 ppm, as can be seen in Figure 4. The maximum current used was only 8 amperes because the given operating condition is not possible if increased. The current of 8 amperes resulted in uranium deposit attached to the Pt cathode of $78.40 \mathrm{mg}$ or $27.74 \%$, and a concentration decrease in feed solution after the electroplating process was $38.01 \%$. The amount of uranium deposit attached to the cathode is in accordance with the Faraday's formula, which states that the larger the current the more product will be obtained. If the current strength is raised to 9 amperes, for example, theoretically it would result in more uranium deposit, but the the solution temperature would increase and evaporation will start to take place, which can cause volume reducing. In 
anticipation of this occurence, experiment could not be done at a current strength of more than 9 amperes.

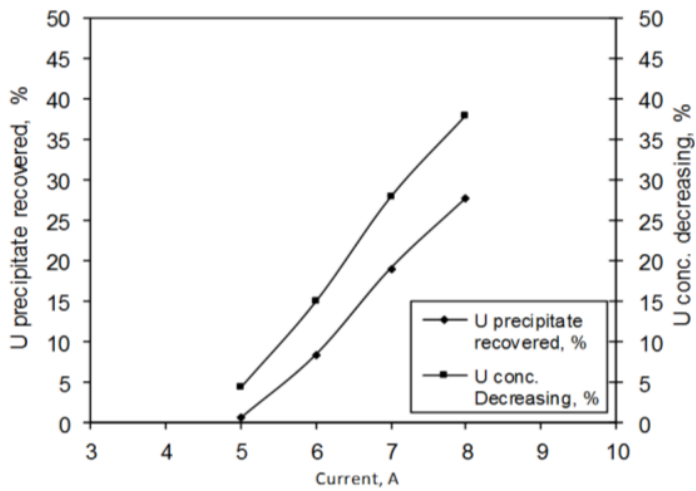

Figure 4. Effect of current on $\mathrm{UO}_{2}$ recovered and acidity decreasing of feed.

To determine the relative good condition, there should be a specific weight ratio for the effective cathode area submerged in different solutions between $\mathrm{Pt}$ and SS cathodes for 1 hour electroplating time at varied current. Pt cathode with a circular effective area (of the submerged portion in the solution) of $15.9 \mathrm{~cm}^{2}$, while the SS rectangular cathode has an effective area of $22.5 \mathrm{~cm}^{2}$. Figure 5 shows the influence of current on the effective precipitate obtained at the cathode electrode based on the type and feed. For the uranyl nitrate feed, the electrode used was $\mathrm{Pt} / \mathrm{Pt}$ (anode/cathode), while the process effluent feed used $\mathrm{Pt} / \mathrm{SS}$ and $\mathrm{Pt} / \mathrm{Pt}$ electrodes from previous study[15]. It appears that for process effluent feed with varied current, the $\mathrm{Pt} / \mathrm{Pt}$ electrode provides greater specific weight of uranium attached to the cathode than that of the $\mathrm{Pt} / \mathrm{SS}$ electrode. Electrode materials affect the performance of the electroplating process. Platinum $(\mathrm{Pt})$ is inert, and so it neither react with other elements, nor redox reaction. It does not dissolve well in acidic or alkaline solvent and is corrosion resistance. The use of Pt as anode does not cause the formation of $\mathrm{Pt}$ metal deposition on the cathode, which can add impurities. Instead, electrodes from other metals, for example $\mathrm{Cu}, \mathrm{Au}, \mathrm{Fe}, \mathrm{SS}$ and $\mathrm{Zn}$, as active electrode will possibly react with other elements or compounds in the solution, and they are easily corroded.

The use of $\mathrm{Pt}$ cathode at varied current for uranyl nitrate and process effluent feed[15] produces specific more precipitate weight than using SS cathode with process effluent feed. This may be caused by the degree of purity of SS cathode is lower than taht of $\mathrm{Pt}$ because SS is a metal alloy containing several elements such as $\mathrm{C}, \mathrm{Fe}, \mathrm{Cr}, \mathrm{Ni}$, etc. The uranyl nitrate feed gave a greater specific amount of precipitate compared to that of the process effluent feed.

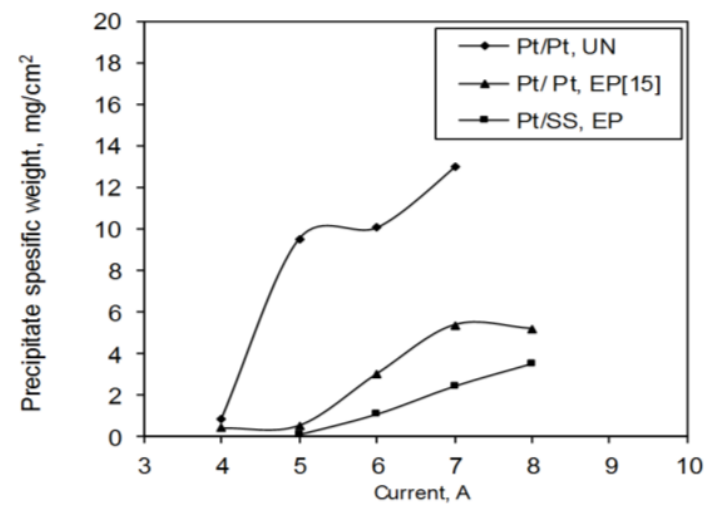

Figure 5. Relation between current and specific weight of precipitate at cathode

where:

UN : uranyl nitrate feed

$\mathrm{Pt} / \mathrm{Pt}$ : Pt Anode, cathode Pt

EP : process effluent feed

Pt/SS : Pt Anode, cathode SS

This is understandable because the process effluent contains a lot of impurities, especially if there are cations with standard reduction potential greater than that of uranium, such as $\mathrm{Fe}, \mathrm{Cu}, \mathrm{Mn}, \mathrm{Sn}$, where it will be reduced first and causes competition with $\mathrm{UO}_{2}{ }^{++}$cation during the deposition process on the cathode. In comparison, for the use of Pt cathode with uranyl nitrate feed and the SS cathode with process effluent feed, it was obtained a specific weight of 
uranium in the cathode respectively of $12.99 \mathrm{mg} / \mathrm{cm}^{2}, 2.4 \mathrm{mg} / \mathrm{cm}^{2}$ and $5.37 \mathrm{mg} / \mathrm{cm}^{2}$ for 7 ampere current for 1 hour electroplating ${ }^{[15]}$.

\section{Deposition analysis using $\mathrm{XRD}^{[15]}$}

For the determination of the phase of uranium compounds attached to the $\mathrm{Pt}$ cathode, analysis of precipitate derived from process effluent feed using XRD had been done and the results were reported in reference 15 . It was mentioned in reference 15 that the precipitate contains uranyl nitrate hydroxide hydrate $\quad\left(\left(\mathrm{UO}_{2}\right)_{2} \quad(\mathrm{OH})_{2} \quad\left(\mathrm{NO}_{3}\right)_{2}\right.$ $\left.\left(\mathrm{H}_{2} \mathrm{O}\right)_{4}\right)$ formed by the reaction of uranyl nitrate $\mathrm{UO}_{2}\left(\mathrm{NO}_{3}\right)_{2}$ in process effluent with ammonium hydroxide $\left(\mathrm{NH}_{4} \mathrm{OH}\right)$ as alkaline for $\mathrm{pH}$ adjusting of the feed to be at 1.8 and $\mathrm{H}_{2} \mathrm{O}$, ammonium nitrate $\left(\mathrm{NH}_{4} \mathrm{NO}_{3}\right)$ due to the reaction with ammonium nitrate ion, as well as the compound of $\mathrm{UO}_{2}$ and $\mathrm{U}_{3} \mathrm{O}_{8}$. However, but it did not appear to have uranium in metallic form, although allegedly has actually been formed but is oxidized back into oxides ${ }^{[15]}$. In order to obtain precipitates in the form of uranium metal at the cathode, it is possible if the current or voltage is enlarged again and the capacity of the electroplating cell is increased ${ }^{[15]}$.

In this research, a feed solution of uranyl nitrate was used and the compounds obtained were also expected to be in the form of $\mathrm{UO}_{2}$ and $\mathrm{U}_{3} \mathrm{O}_{3}$ as precipitates that attached at the cathode, in addition to a complex compound of uranyl nitrate hydroxide hydrate.

Therefore, a method of uranium precipitaes deposition at a cathode has given results that in the method of electroplating, the process of collecting uranium from a solution containing uranium can be carried out, the results of which are in the form of uranium oxide as solid form. This method has the advantage as to shorten the process compared with the method of extraction, ion exchange, electrodialysis, etc.

\section{CONCLUSIONS}

From the electroplating experiment it can be concluded that there has been a process of uranium ion movement from the solution toward the cathode and stuck as precipitate as product. During the process, the amount of current and time affect the results of uranium deposit attached to the cathode. The greater the current is used the greater the uranium products will be precipitated or attached to the cathode. This is also true for the time effect, the longer time the electroplating process progresses the greater amount of results are obtained in accordance to Faraday's law. Longer time for the electroplating process has resulted in more uranium deposit attached to the $\mathrm{Pt}$ cathode. For a period of time of 1 hour and 7 ampere current, the uranium deposit obtained was $74.96 \%$ and weight of uranium in the feed was $206.5 \mathrm{mg}$. Only after 1 hour of operation did the precipitation decrease due to saturation of the cathode for accom-modating the uranium precipitates attached. The most influential parameters in the experiment were current and time.

The type of feed and cathode also affects the amount of uranium precipitate attached to the cathode, which can be seen from the specific weight. Uranyl nitrate feed gave better results than the process effluent feed because uranyl nitrate was relatively purer than the process effluent. Stainless Steel (SS) planchet can be used as a cathode material, but it gave the amount of preci-pitate less than that of platinum (Pt). For the process effluent feed with Pt and SS cathodes, the specific weight of uranium attached to the cathode was of $2.4 \mathrm{mg} / \mathrm{cm}^{2}$ and $5.37 \mathrm{mg} / \mathrm{cm}^{2}$ respectively, while the use of Pt cathode with uranyl nitrate as feed has produced a specific weight of precipitate of $12.99 \mathrm{mg} / \mathrm{cm}^{2}$ at 7 ampere current. 


\section{ACKNOWLEDGMENTS}

The author would like to deeply thank to Mr. Noor Yudhi A.Md, Sunardi A.Md, Yatno Dwi Agus S, Suyoto S.ST, BFBBN staff and technicians who have assisted in the experiment until the completion of the research.

\section{REFERENCES}

[1] H. Guettaf, A.Becis, K. Ferhat, K. Hanou, D. Bouchiha, K. Yakoubi and F. Ferrad, (2009), ConcentrationPurification of Uranium from an Acid Leaching Solution, Physics Procedia, 2, 765-771.

[2] Abdelmajid A. Adam, Mohamed Ahmed H. Eltayeb, Omar B. Ibrahim, (2014), Uranium recovery from Uro area phosphate ore, Nuba Mountains, Sudan, Arabian Journal of Chemistry, 7, 758-769

[3] Sprynsky, M., Kovalchuk, I., Buszewski, B., (2010), The separation of uranium ions by natural and modified diatomite from aqueous solution. J. Hazard. Mater. 181, 700707.

[4] Majdan, M., Pikus, S., Gajowiak, A., Sternik, D., Zieba, E., (2010), Uranium sorption on bentonite modified by octadecyltrimethylammonium bromide. J. Hazard. Mater. 184, 662670.

[5] Deliyanni, E.A., Bakoyannakis, D.N., Zouboulis, A.I., Matis, K.A., (2003), Sorption of $A s(V)$ ions by akaganeitetype nanocrystals. Chemosphere 50, 155-163.

[6] Mellah, A., Chegrouche, S., Barkat, M., (2006), The removal of uranium (VI) from aqueous solutions onto activated carbon: kinetic and thermodynamic investigations. J. Colloid Interface Sci. 296, 434-441.
[7] Ghasemi, M., Keshtkar, A.R., Dabbagh, R., Safdari, S.J., (2011), Biosorption of uranium (VI) from aqueous solutions by Ca-pretreated Cystoseira indica alga: breakthrough curves studies and modeling. J. Hazard. Mater. 189, 141-149.

[8] Leila Dolatyari, Mohammad Reza Yaftian, Sadegh Rostamnia, (2016), Removal of uranium (VI) ions from aqueous solutions using Schiff base functionalized SBA-15 mesoporous silica materials, Journal of Environmental Management 169, 8-17

[9] Ghaib Widodo, Hendro Wahyono, Ratih Langenati, Sigit, (2010), Aplikasi Metoda Elektrodialisis Untuk Pemisahan Uranium Dari Efluen Proses, Jurnal URANIA, Vol. 16, No. 3, 122131

[10] Sigit, Ghaib Widodo, Ratih Langenati, Torowati, Noor Yudhi, (2010), Pengaruh Tegangan, Waktu Dan Keasaman Pada Proses Elektrodialisis Larutan Uranil Nitrat, Jurnal Teknologi Bahan Nuklir, Vol. 6, No. 1, ISSN 1907-2635, 28 - 40,

[11] Noor Yudhi (2007), Pemungutan Uranium Di Dalam Efluen Proses Kimia Dengan Electroplating, Pusat Teknologi Bahan Nuklir, Serpong, Hasil-Hasil Penelitian EBN Tahun 2007, ISSN 0854-5561, 142-146.

[12] Widodo, G., Rahmiati, dan Mujinem, (2014), "Pengaruh Penjeratan Asamasam Terhadap Penurunan Kadar Uranium dan Impuritas Dalam Efluen Proses", Jurnal Teknologi Bahan Nuklir, Vol. 10. No. 1, PTBBN-BATAN, Serpong.

[13] Saleh, A. A., (2014), Electroplating. Teknik Pelapisan Logam dengan Cara Listrik, Bandung, C.V. Yrama Widya, ISBN 978-602-277-161-6 
(Sigit, Ghaib Widodo, Bangun Wasito, KrisTri Basuki, Fahrunissa)

[14] Helen, H. Lou and Y. Huang, (2006), Electroplating, Encylopedia of Chemical Processing; Taylor \& Francis. DOI: 10.1081/E-ECHP120007747
[15] Fahrunissa, (2015), Pemungutan Uranium Dari Efluen Proses Dengan Metode Elektroplating, Tugas Akhir Sarjana Sains Terapan, Sekolah Tinggi Teknologi Nuklir, Yogyakarta. 
